Scottish Tradition $\mathfrak{O} 0 \mathrm{l} .272002$

\title{
WitchCraft and Family: What Can Witchcraft Documents Tell Us About Early Modern Scottish Family Life?
}

$[T]$ o detect the signs and gestures which disclose their [families] interior emotional life, we must attend very closely indeed to "economics" - or to that daily occupation (farming, fishing, weaving, begging) which gives us their way of living: a way of living which was not merely a way of surviving but also a way of relating and valuing ... for the vast majority throughout history, familial relations have been intermeshed with the structures of work. ${ }^{1}$

$\mathrm{t}$ is difficult to document family life for the average early modern Scot. Diaries, letters and other personal and business correspondence relating to family life survives for high ranking members of Scottish society such as kings, queens, nobles and merchants. ${ }^{2}$ Ministers and other religious figures have left us some writings about their faith that may be fruitfully used for understanding how families worked and what people thought about them. ${ }^{3}$ But these sources were usually written by educated men and may not reflect the bulk of society, including most women, who could not write. Wills, testaments, deeds, sasines, estate management, baronial, and burgh court records provide much concrete detail about land holdings and the physical make-up of communities, but they can be barren on cultural detail and emotional life. They too are skewed towards men. The commissariat records have been used to good effect to study divorce, but the documents do not survive for most of the early modern period. ${ }^{4}$ The processes of Kirk Session and Presbytery investigations of 'disciplinary' infractions (including adultery, fornication, speech crimes, marital discord, popular 


\section{Scottigh Tradition $\mathfrak{Y} 01.272002$}

festivals and rituals, penny-weddings and lyck-wakes) tell us about normative rules. The frequency of punishment, fines and penance suggests that people's everyday behaviour usually fell short of those rules. ${ }^{5}$ Although their survival is patchy for the early part of the early modern period, they record some of the daily chatter of everyday life, and as such are an invaluable source for family studies.

A wide range of document-types survive for the early modern period. But random survival rates of potentially detailed documents coupled with their often significant lack of detail about women and the lower orders means that at this stage we do not know even the very basics about family life, let alone people's subjective thoughts and experiences of family. Without a picture of women's lives half of the family remains shrouded. Without information about non-elite families our understanding is biased. Without some documentation of the culture of family life we are left with a bland, skeletal outline. Research by the Survey of Scottish Witchcraft can help. It has turned up a wealth of detail about families, households and community life for middling and lower status men and women-potentially helping to fill some gaps. ${ }^{6}$ And, the substance of witch belief and the processes of witchcraft denunciation, investigation and trial documented people's thoughts, fears and subjective experiences of their families. ${ }^{7}$

Witchcraft documents have two inherent weaknesses that need to be overcome to present an accurate portrayal of early modern life. First, the communities documented by witchcraft accusations may be anomalous. Most people in early modern Scotland did not live through a witchcraft accusation, and most communities did not formally accuse one or more of their members of witchcraft. So, witchcraft documents do not concern 'normal' community relations; they need to be placed alongside families from other sources, possibly Kirk Session, Presbytery and burgh court minutes. But, they do give us a window into some communities during the development and fruition of a crisis. Second, the testimony recorded in witchcraft documents about family life, households, land holding and community needs to be cross checked in other documents because witness testimony was constructed from memory. Memory can sometimes exaggerate or diminish people's wealth, suffering or importance under the shadow of witchcraft suspicions. 


\title{
Scottish Tradition 2001.272002
}

\author{
I
}

It is no surprise to witchcraft scholars that witchcraft documents provide unexpected flashes of insight about family life. Most witchcraft accusations grew out of decades of quarrels and curses between neighbours. ${ }^{8}$ The quarrels usually concerned women's work, household boundaries and community tensions. Thus as a community turned against one of its members, they left us documents that reveal a great deal about the social backdrop to family life (household, community, work); the emotional ties between family members and neighbours; the lines of community love and distrust, alliance and feud, quarrels and cooperation. Witchcraft documents are essentially a community talking about how things went wrong (i.e. bad luck, animals dying, poor harvests, sick family members, quarrels and contentions and failed magical healing attempts) and how to fix them.

Witches were accused in Scotland through one of two ways. An accusation started with the 'neighbourhood witch'. The neighbourhood witch was denounced by neighbours for causing magical harm to community members, usually after quarrels that led to verbal abuse and curses. It usually took decades for a witchcraft reputation of this kind to develop and lead to an official denunciation to the church or magistrates. Sources from this type of accusation often provide rich documentation of family and community life. Sometimes, the investigation into a neighbourhood witch led to a larger panic - either the neighbourhood witch confessed and denounced others or local authorities panicked and sought more suspects. Roughly half of the people accused of witchcraft in Scotland were prosecuted during panics that were local, regional, or semi-national in scope. Panic cases, however, do not usually provide detailed social or economic information. They usually concern demonic witchcraft, witches' meetings, or else contain very little information at all.

Witchcraft documents suggest that 'family', seen solely in terms of kin relations and emotional ties, is not really wide enough to grasp the full range of experiences of early modern families in Scotland. Families organised inheritance (i.e. access to land, craft tools, burgess status, etc.) and work (i.e. the labour of husbands, wives, children and servants). Witchcraft documents show that families did not function in isolation. Work happened within households, ${ }^{9}$ which were constrained and shaped by 


\section{Scottigh Tradition $\mathfrak{Y} 01.272002$}

community decisions, competition and co-operation. ${ }^{10}$ Following a large body of work on the family, witchcraft documents also caution against viewing the family through the dichotomy of either organising work or structuring emotional ties. ${ }^{11}$

II

Whose families can witchcraft documents tell us about? The Survey of Scottish Witchcraft has begun to piece together a comprehensive picture of the range of people that witchcraft documents concern. Thus far the Survey has documented 3085 people accused of witchcraft in Scotland between 1563 and 1736. ${ }^{12}$ Most of these cases record very little information beyond name and date. However a core of roughly 100 cases provides solid and compelling social and cultural information about family, household and community relations surrounding the accused witch. Approximately 200 additional cases contain partial, supplemental information. ${ }^{13}$

The cases documented in the Survey of Scottish Witchcraft can yield some quantitative information about the accused witch and her (or his) life, including: sex, marital status, socio-economic status, occupation (of the witch or the accused witch's spouse), and residence (burgh, rural, region, etc.). But, their main strength for family and other social studies is their qualitative detail.

Women, at roughly 80 per cent of accused witches, are the largest single group covered by witchcraft documents. But this does not mean that witchcraft documents say nothing about men. Quite the contrary, they tell us about male witches, the male family members of accused witches, and male witch-hunters. ${ }^{14}$ So far the Survey of Scottish Witchcraft has found details on 281 husbands, 49 sons, 42 fathers and 22 brothers of accused witches. Interestingly witchcraft documents tell far less about the female relatives of female accused witches. The Survey has also found over 1000 men who were involved as witchcraft investigators and prosecutors - some of whom were very active in hunting large numbers of witches. Witch hunters were almost always men and they were usually local lairds and their assistants or ministers. These were the men who orchestrated and shepherded the investigation and trial of accused witches in their localities.

Most suspected witches were married. ${ }^{15}$ Marital status may not seem like compelling information for family studies, but for 


\section{Scottigh Tradition $\mathfrak{O} 0 \mathrm{l} .272002$}

married women, marital status and a husband's name are crucial for building a family picture from a variety of documents. Without a husband's name, it is very difficult to find married women in other sources because women kept their maiden names after marriage and most sources pertain to men. Even the simple matter of identifying the children of married women is difficult without her husband's surname. A small detail, such as the name of an accused witch's husband, can open up other sources and make it possible to reconstruct a family's way of living and social status.

The Survey of Scottish Witchcraft has made an attempt to provide socio-economic classifications of accused witches where possible. ${ }^{16}$ Status and ranking of people below the nobility, in early modern Scotland, is notoriously difficult to work out. For example, someone labelled 'servant' could be a poor day-labouring farm worker, or a Lord's factor. But, witchcraft documents can help us understand some early modern social categories because they often list the household's occupation (or the husband's) in combination with detailed descriptions of people's daily working habits and their possessions. Preliminary analysis of the Survey of Scottish Witchcraft database shows that most people accused of witchcraft were of middling and lower status - they were the integral members of their local communities. ${ }^{17}$ High status people either avoided denunciation or fought off charges at an early stage. ${ }^{18}$ Sometimes vagabonds and beggars were accused of witchcraft but this was usually during panics. These social groups were not prime targets when a community turned against one of its own with an accusation of witchcraft.

Witchcraft documents tell us about women from eight different personal occupations including, henwife, midwife, nurse, schoolteacher, schoolmaster, servant, shop-keeper and vagabond. The marital status of women in occupations is not usually known, but the main exceptions were the schoolteacher who was single and a few married midwives and servants. Most married women were designated with the occupations of their husbands, rather than their own. Husbands of suspected witches ranged in 38 different occupations - covering a wide crosssection of early modern Scottish society. ${ }^{19}$ Married female witchcraft suspects, like most married women, laboured as partners to their husbands. Witchcraft documents show husband and 


\section{Scottigh Tradition $\mathfrak{Y} 01.272002$}

wife living and working as a social and economic team, as will be made clear below.

While most witches were from rural backgrounds, a sizeable minority were from towns. Witchcraft documents reflect regional variations in settlement types, work patterns and cultural traditions. Documents survive for suspects from coastal and inland areas; rural and town; and east, west, north and south (including Orkney and Shetland) providing information about families from all over Scotland. Unfortunately, there are very few accused witches that we know about from the Highlands, leaving a sizeable gap in our knowledge.

The marital status, socio-economic status, occupation and residence of accused witches represents a sizeable body of information about early modern families. In terms of family, the main strength of witchcraft documents does not lie in counting, but in the wallpaper of detail behind accusations of magical harm.

\section{III}

What do witchcraft documents tell us about families? To understand the early modern family, we need to know who counted as 'family', how people in 'families' related to one another and their communities, and what people thought about their families. Witchcraft documents, unfortunately, do not tell us very much about how people reckoned kinship beyond the obvious and what is already known from other sources. ${ }^{20}$ But, witchcraft documents do provide provocative hints about how family members related to one another and how families sat (sometimes uneasily) within their households and communities. The idea of one static, uniform, early modern family is shattered by the sheer variety of families described in witchcraft documents. Witchcraft families show variation by region, social status, temperament and the particular place in the life cycle of any given household.

The witchcraft case against Isabel Young, from East Barns, Dunbar (along with other supporting examples in footnotes) will be used to demonstrate the kinds of information about families contained in witchcraft documents. ${ }^{21}$ Isabel Young was probably near 70 years of age when she was tried for witchcraft, but the documentation provides 40 years of community commentary on her and her family. 


\section{Scottigh Tradition $\mathfrak{O} 0 \mathrm{l} .272002$}

Isabel Young was married with four married sons at the time of her trial. Her husband's name was George Smith. ${ }^{22}$ Knowing George's name opened up a variety of sources that document their family and household. Thus, it has been possible to crosscheck and add substantive detail to the information contained in the nearly 20 lengthy and detailed witchcraft documents. Isabel and George owned animals, barns, and outbuildings, they employed at least five servants and Isabel engaged in a variety of work experiences including bartering, money lending, and the usual work of the household. ${ }^{23}$ Isabel was first accused of witchcraft in 1619 and was eventually tried and executed for witchcraft in 1629. ${ }^{24}$

George Smith was described in many documents as a portioner. ${ }^{25}$ This could indicate a wide range of socio-economic positions, but through a combination of witchcraft and other documents we know that in this case 'portioner' meant that they occupied (at least) one sixteenth of the estate of East Barns and were on the bottom rung of the local elite. ${ }^{26}$ Many of Isabel's accusers and victims also appear in other documents, so it is possible to see the social background of her accusers and how they interacted with her and her family. Unluckily for Isabel, about half of the other portioners' households turned against her, including Thomas Home, the richest man in the East Barns community. The documents suggest that Isabel's family and household were deeply intertwined in the business and emotional life of other families in East Barns and beyond. As we shall see, families like Smith-Young and their neighbours were usually tied together in webs of debt, renting, borrowing and quarrelling.

These documents allow for the creation of a picture of the material conditions in which the Smith-Young family lived. We know that they had a barn and many cattle because Isabel was accused of conducting a protective magic ritual on her cattle in front of their barn. ${ }^{27} \mathrm{~A}$ quarrel with Thomas Home, the man to whom Smith paid some of his rents, tells us that Isabel and her husband had the use of two cottar's dwellings and one rig of land from Home. ${ }^{28}$ The Great Seal tells us that they were feuars with a potentially heritable stake in at least some of their occupied lands. Witchcraft documents tell us Smith farmed his own land using a plough he shared with neighbours. ${ }^{29}$ By 1622 , Young and Smith were provided for with life rent from one of their married 


\section{Scottigh Tradition $\mathfrak{Y} 01.272002$}

sons who consolidated their land holding and rented lands. ${ }^{30}$ It is unclear how much physical labour Smith and Young did after this point because they would have been between 60 and 70 years old. Documents suggest that by about mid-way through the life-cycle of the Smith-Young household, they rented and occupied lands slightly beyond their means for a time as a strategy to accumulate more land to pass on to their married sons. ${ }^{31}$

Smith-Young's livelihood was well above most families in East Barns, but as stated earlier their social level was the lowest of the well-off group. Witchcraft documents tell us how they felt about this position. While attending a baptism, Isabel's neighbour Margaret Ogill called her 'Lady Young'. In reply, Isabel reportedly said that she should be called 'Lady Home' because her husband 'hes gottin [Thomas] Homeis landis and will get moir.' 32 This exchange carried a long history of neighbourly discord and co-operation. The two households had been embroiled in Kirk Session denunciations about adultery, raising a bastard son, folk healing and excessive quarrelling; while at the same time they shared oxen, a chair-rig, labour power, ready cash and produce. John Nisbet, Ogill's husband, had just recently outbid George Smith for the use of Thomas Home's land, using cash he had borrowed from Smith-Young. At the baptism, Isabel told the whole community who she thought should be occupying Home's land.

Smith-Young also had long-standing disputes with Thomas Home and his family spanning 30 years and three of his wives. Neighbours testified that in revenge for a land dispute Isabel magically battered the Home household, eventually destroying it. ${ }^{33}$ She supposedly magically destroyed Thomas Home's dovecote, a source of poultry and a status symbol. ${ }^{34}$ After this the Home's cows died, Thomas Home himself died and his house burned down leaving his widow and children homeless. It was as if once the dovecote, a symbol of his wealth and power, was drained the rest of his household was thought vulnerable. After his death, Isabel's son took possession of Home's land, seen by many as a fulfilment of the words she spoke at the baptism. The Smith-Young household was on the property ladder and fighting to get higher.

Beyond giving us the outlines of their material lives, the documents also hint at Smith-Young's emotional family space. 


\section{Scottigh Tradition $\mathfrak{O} 0 \mathrm{l} .272002$}

Two separate indictments and the supporting witness testimony of 11 people tell us that the relationship between Isabel and George was sometimes violent. ${ }^{35}$ So much so that members of the community believed that she had tried to kill him with harmful magic while he worked their fields. George Smith must have also believed his wife tried to kill him because he gave evidence against her. ${ }^{36}$ In this she was not alone, other accused witches were believed to have tried to kill their husbands. ${ }^{37}$ The defence stated that Isabel was not the violent one in their relationship because George had at one time tried to kill Isabel with a sword and left a scar. Not all accused witches had such difficult relationships with their spouses. ${ }^{38}$

Three of her married sons supported her throughout her trial as prolocutors in her defence, alongside two paid advocates. Other cases demonstrate that it was not unique for children to support their mothers (and fathers) through a witchcraft accusation, ${ }^{39}$ but the few cases where children did testify against their parents make painful reading. ${ }^{40}$ The testimony of community members and her family show that Isabel reciprocated the strong emotional attachment of her children. She was very protective of both her sons and her younger brother, even after they were married. ${ }^{41}$ She instigated verbal quarrels that later led to witchcraft accusations while advocating for jobs and respect for her married male family members. Indeed, many witchcraft documents show mothers - both married and widowed - maintaining very close relationships with their married children. ${ }^{42}$ Disappointingly, the documents say very little about infants or young, unmarried children and in general information about children is anecdotal. ${ }^{4}$

Infants were discussed in witchcraft documents only when they were the perceived victims of witchcraft attacks. The frequency with which infants were pawns in magical struggles could mean that they were deemed important to household survival or that they were seen as a household's weakest point by being dependent. Many families who saw themselves as witchcraft victims described episodes where an infant's body became the battleground between the suspected witch and her chosen victim. A few adolescents were accused of witchcraft including Jean Rob aged 14, James Welch aged 15, and Anabell Stewart aged 14 . While their testimony was used, they were usually 


\section{Scottigh Tradition $\mathfrak{Y} 01.272002$}

deemed too young for trial. Sometimes child witches accused their parents, but more work needs to be done to understand this phenomena. Adolescents were also mentioned in the two Scottish episodes of demonic possession from 1697 and 16991700 , leading to the trials of 48 people. The main 'victims' of possession were adolescent girls who denounced upwards of 50 people for causing their demonic possession. Again, much more work needs to be done to understand the family dynamics of demonic possession.

In-law relationships are particularly difficult to document in witchcraft sources. ${ }^{44}$ Most of the evidence in witchcraft documents present bad in-law relationships. ${ }^{45}$ This was certainly the case with what can be pieced together about Isabel's in-laws. Isable's son John Smith married Margaret Bryson. Isabel had a history of quarrelling with the Bryson family about unruly children, factional neighbourhood alliances and daily farm work. Isabel and Patrick Bryson (Margaret's uncle) had a particularly bitter argument about Isabel's swine tether that led to accusations of witchcraft. Patrick Bryson occupied twice as much land as Smith-Young. ${ }^{46}$ Although Smith-Young had married their son up the social ladder, Isabel was jealous of her in-laws. She said in a threatening manner that Elspeth Bryson (Patrick's daughter) 'was becoming ane wealthie woman haifing abundance of geir' ${ }^{47}$ The East and West Barns community interpreted this statement as a 'feirfull and devilische salutation' that caused the Bryson house and crops to burn. ${ }^{48}$ Despite all of this, their children were married. It is not clear if they married against their parent's wishes or to the contrary as an attempt to repair the damaged relationship.

Family life was not lived only with kin as households incorporated servants. Isabel seems to have been close to Alison Lummisden, one of her servants who witnessed part of a protective magic ritual involving a cat, some salt and a live ox. ${ }^{49}$ Alison testified that Isabel was a virtuous and honest woman. This was potentially dangerous as some servants were charged with witchcraft along with their employers. ${ }^{50}$

This very brief discussion of Isabel Young's case demonstrates the kind of information witchcraft documents can provide about the family relations of ordinary Scots women and men..$^{51}$ The accumulated body of evidence about witchcraft trials 


\section{Scottigh Tradition $\mathfrak{O} 0 \mathrm{l} .272002$}

contains many more cases like Isabel Young's that could be used to reconstruct other families and households.

\section{IV}

Witchcraft accusations concern misfortunes, discord and quarrels. There are few descriptions of fun events and happy times. Therefore, on their own witchcraft documents could lead to a skewed picture of early modern life as unhappy and difficult. Some documents and testimony in witchcraft trials provide rare glimpses of people enjoying life, going to parties, joking, and sticking together. But, the negative bias inherent in witchcraft documents must be born in mind when used as a source for family life and other sources are necessary to provide balance.

In Isabel Young's case and those of other accused witches, we have a potentially rich body of documentation that, when supplemented by other existing sources, can provide new information about families and fill gaps in currently used documents. If read for their social, cultural and economic subtext, witchcraft documents can provide qualitative texture to our understanding of how ordinary people lived their lives in Scotland's past.

Lauren Martin

University of Edinburgh

\section{Endnotes}

1 E.P. Thompson, 'Happy Families,' New Society (8 Sept. 1977), pp.499-501, review of Stone, The Family. Quoted in H. Medick and D.W. Sabean (eds.), Interest and Emotion: Essays on the Study of Family and Kinship (Cambridge, 1984), p.22.

2 For example, see R.K. Marshall, The Days of Duchess Anne: Life in the Household of the Duchess of Hamilton 1656-1716 (East Linton, 2000); K.M. Brown, Noble Society in Scotland: Wealth, Family and Culture, From Reformation to Revolution (Edinburgh, 2000); M. Sanderson, Mary Stewart's People: Life in Mary Stewart's Scotland (Edinburgh, 1987); J.G. Fyfe (ed.), Scottish Diaries and Memoirs 1550-1746 (Stirling, 1928).

3 L.E. Schmidt, Holy Fairs: Scottish Communions and American Revivals in the Early Modern Period (Princeton, 1989); L. A. Yeoman, 'HeartWork: Emotion, Empowerment and Authority in Covenanting Times,' (PhD thesis, University of St. Andrews, 1991). 


\section{Scottish Tradition $\mathfrak{Y} 0 \mathrm{l} .272002$}

$4 \quad$ L. Leneman, Alienated Affections: The Scottish Experience of Divorce and Separation, 1684-1830 (Edinburgh, 1998).

5 See, R. Mitchison and L. Leneman, Girls in Trouble: Sexuality and Social Control in Rural Scotland, 1660-1780 (Edinburgh, 1998); M. Graham, The Uses of Reform: 'Godly Discipline' and Popular Behaviour in Scotland and Beyond, 1560-1610 (Leiden, 1996).

$6 \quad$ See C. Larner, Enemies of God: The Witch-Hunt in Scotland(London, 1981). Survey of Scottish Witchcraft (SSW) (www.arts.ed.ac.uk/witches) is an online, searchable comprehensive database of accused witches and cultural, social and trial information about them. The database is accompanied by a detailed description of the contours of Scottish witchcraft persecution and belief. All citations to cases below refer to their case number in the Survey of Scottish Witchcraft database. All further references and details can be found on the website after 31 January 2003 using either the case number or the name and date. The project is funded by a British Government research grant from the Economic and Social Research Council.

7 N.Z. Davis has shown how criminal records can be used for social history from below in Fiction in the Archives: Pardon Tales and Their Tellers in Sixteenth-Century France (Cambridge, 1988). C. Ginzburg demonstrates the importance of witchcraft documents for social history, Night Battles: Witchcraft and Agrarian Cults in the Sixteenth and Seventeenth Centuries (Baltimore, 1983).

8 See, Larner, Enemies of God; R. Briggs Witches and Neighbours (London, 1996); L. Martin, 'The Devil and the Domestic: Witchcraft, Quarrels and Women's Work in Scotland,' in J. Goodare (ed.), The Scottish Witch-Hunt in Context (Manchester, 2002).

9 We must be careful not to assume that families are 'natural' and that family and household are synonymous. See O. Harris, 'Households as Natural Units,' in K. Young and C. Woldowitz (eds.), Of Marriage and the Market (London, 1981); O. Harris, 'Households and Their Boundaries,' in History Workshop Journal 13 (1982), pp.143-52; W. Roseberry, 'The Ideology of Domestic Production,' in Labour, Capital and Society 19 [1] (April, 1986). H. Moore, Feminist and Anthropology (Minneapolis, 1988) provides a good review of women, work and family in anthropological literature and feminist revisions and critiques.

10 In his consideration of how historians and anthropologists have thought about family, household and the domestic mode of production, W. Roseberry wrote: '... [E]ven where households may have been central units of production, basic production decisions, as well as room for individual maneuver on the short term, were mediated by communities. . Although production was not communal, 


\section{Scottigh Tradition $\mathfrak{O} 0 \mathrm{l} .272002$}

the community constituted an important relation of production' in 'The Ideology of Domestic Production,' p.79.

11 See, Medick and Sabean (eds.), Interest and Emotion, 1984. They critique the tendency of anthropologists and social historians to operate through the oppositions - structure and agency, material interest and emotional attachment, objective and subjective - when examining family and kinship. They wrote: ' $[R]$ ather than carefully sorting out the nature of rights and duties, claims and counterclaims within families in different social and cultural contexts and delineating the corresponding specific territories in which emotion, trust, and sentiment are structured, emotions and interest are often treated as opposites which cancel each other out. In addition there is an attempt to legitimate such a view by means of evolutionary or ideological perspectives, which contrast a 'modern' emotionalladen nuclear family to 'traditional' family relations based on a different structure of motives altogether.' (p.10).

12 The statistics presented here are preliminary figures from the Survey of Scottish Witchcraft Database. The figures were current at the time of writing. The project is likely to find at least 300 more cases by the end of the project. Therefore, the figures presented here are not final and should not be quoted. Final figures will be made available on the SSW website after 31 January 2003 (see, www.arts.ed.ac.uk/witches).

13 A 'case' is the information surrounding an accused witch. There are three categories of detail for cases. The first category can be eliminated from a social analysis. These are cases with almost no social information - nearly half the cases (1659). Many of these were prosecuted during panics. The second category is a pool of cases with at least some useful information. It is estimated that roughly 300 fit this category (277 for sure). The third category is a detailed core of cases drawn from category two, about 100 extremely rich cases. It is currently unknown where the remaining 1000 cases fit. It is likely that some of them might be useful for family studies, but that most will not.

14 See, SSW website.

15 Marital status is known for only one-fifth of accused witches, of those a large majority were married (78 per cent), some were widowed (20 per cent) and very few were single (2 per cent).

16 For a comprehensive breakdown of socio-economic status and occupation of accused witches and their families, see SSW website.

17 It is usually too difficult to ascertain socio-economic status and most cases do not contain enough information to make such a categorisation. So, socio-economic status has been assigned to only one-tenth of the accused witches in the database. Of them, 64 per 


\section{Scottigh Tradition $\mathfrak{Y} 01.272002$}

cent were middling and 21 per cent were lower status - a total of 85 per cent. The rest were mostly of very low status, such as beggars, vagabonds or other social outcasts. One-tenth may seem low, but it represents nearly 300 people (mostly women) with enough information to aid in the reconstruction of family, household and community. Nearly all of the very well documented cases had enough information to assign socio-economic status. For definitions of these categories see the SSW website.

18 High status people were only six per cent of accused witches with known socio-economic status. This is probably an accurate count because a clerk would not fail to mention lord, laird or very high status. With this in mind, there are not likely to be very many uncounted high status people lurking in the vast majority of cases for which socio-economic status is not known. Therefore, the 18 high status accused witches represent only .006 per cent of known witches.

19 Some of the occupations of female witchcraft suspects included servants, midwives, colliers, vagabonds, shopkeepers, teachers and more. The occupations of male witches and husbands of female witchcraft suspects include farmers, sailors, skippers, millers, maltmen, all manner of craftsmen (weavers, tailors, cordiners, candlemakers, etc.), colliers, cottars, and more. For a complete occupation breakdown see the SSW.

20 Early modern Scots recognised both cognatic and agnatic kinship networks that created bonds of responsibility and support. Married women kept their maiden names and inheritance was primarily patrilineal and secondarily matrilineal. Marriage and incest were regulated by degrees of kinship that were reckoned through both cognatic and agnatic lines. See W. H. D. Sellar, 'Marriage, Divorce and the Forbidden Degrees: Canon Law and Scots Law,' in W. N. Osborough (ed.), Explorations in Law and History: Irish Legal History Society Discourses, 1988-1994 (Dublin, 1995).

21 Isabel Young, 1629 (c/egd/160).

22 The phrase 'Smith-Young' will be used when referring to their family and household.

23 She was responsible for a wide range of tasks, including taking crops to the mill, supervising at least five servants, buying produce (such as wheat, butter and ale), the care of animals and all the other jobs a female head of household did (cooking, cleaning, mending, peat, wood and water gathering, and child rearing). In National Archives of Scotland (NAS) JC26/9/1 references to her work are scattered throughout the 21 indictments against her.

24 She was investigated by the Kirk Session of Dunce. Alexander Fortune, described as a healer, gave testimony regarding a sore 


\section{Scottigh Tradition $\mathfrak{O} 0 \mathrm{l} .272002$}

under Isabel's left breast that he was unable to heal. He claimed that gossip called it a Devil's mark.

25 Many witchcraft documents tell us about the occupations of the husband of accused witches. These men could potentially be detailed in other types of documents.

26 Much of the reconstruction of East Barns, c.1580-c.1630 was possible with references from The Register of the Great Seal (GS, v.5, \#355, 360, 362, 364-367, 369, 370, 373, 374; GS v.6, \#908, 910, 1097; GS, v.7, \#2160; GS, v.8, \#300; and others). The register of sasines, wills and testaments were also consulted. See, L. Martin, 'The Devil and the Domestic: Women's Work, Marriage and Witchcraft in Early Modern Scotland,' PhD thesis, Graduate Faculty of the New School for Social Research (forthcoming) for full citations.

27 NAS JC26/9/1.

28 NAS JC26/9/9.

29 NAS JC26/9/1.

30 GS v.8, \#300, page 101 . The family worked one rig as feuars and rented more lands from neighbours, for which they seem to have eventually obtained some form of secure tenure.

$31 \quad G S$ v. 6, \#908, 1097; NAS JC26/9/9.

32 NAS JC26/9/1, NAS JC26/9/5, NAS JC26/9/6.

33 Different piece of land than the one in question between SmithYoung and Nisbet-Ogill, NAS JC26/9/1.

34 NAS JC26/9/1.

35 NAS JC26/9/1, NAS JC26/9/5.

36 NAS JC26/9/1, Selected Justiciary Cases (SJC), vol. I (The Stair Society, 1953), pp.102-103.

37 Helen Laying, 1678 (c/egd/692) was convicted of having murdered her husband with witchcraft. Geilles Burnet, 1671 (c/egd/584) was accused of killing two successive husbands with witchcraft.

38 For example, when Elizabeth Bathgate, 1634 (c/egd/173) was accused of witchcraft in 1634 her husband Alexander Pae stood by her and orchestrated her defence. John Hog, 1629 (c/egd/1153) and his wife Margaret Nicholson, 1629 (c/la/2636) were both denounced for witchcraft by Alexander Hammilton, a notorious witch who denounced upwards of 50 other people. In this circumstance many husbands turned against their wives to save themselves. Hog and Nicholson stuck together, put their 'good' reputation as respectable heads of house on the line, and proved their innocence, this despite charges that Hog had unsuccessfully attempted to enter into an adulterous affair with a neighbour's wife.

39 Katherine Crystie's, 1630 (c/egd/1005) son petitioned Privy Council on her behalf for her release from prison. Widowed mothers retained close relationships with their married children. Documents 


\section{Scottigh Tradition $\mathfrak{Y} 01.272002$}

from Janet Cock's case, 1661 (c/egd/409) show that parent/child relationships could be both strong and difficult. Accusations against Janet allege that she was angry with her two daughters when they bought curds and whey without her permission. But after her arrest and first trial, Janet Cock's two daughters wrote an impassioned plea to the Privy Council for the life of their mother (which survives NAS JC26/27/9 item 20).

40 Alexander Lyle, 1700 (c/egd/735) testified that his mother brought him to the Devil.

41 She cursed a man who occupied land she wanted for her son. Also, a quarrel with her cottars occurred because they were given the head shepherd job over her younger brother and this led to witchcraft accusations (NAS JC26/9/1).

42 Neighbourhood testimony shows that Agnes Finnie, 1645 (c/egd/183), accused of witchcraft in 1644, was very close to her daughter and that their close relationship was widely acknowledged. Finnie was a self-sufficient shopkeeper in the Potterrow just outside of Edinburgh. Her community believed that she magically harmed people in revenge for social and economic slights against her daughter and her daughter's husband. This case shows a mother closely involved in her daughter's life, even after she had left home. Likewise, Agnes' daughter had numerous quarrels with neighbours in an effort to defend her mother. This was a significant personal risk because witchcraft reputations sometimes spread from quarrelsome mothers to quarrelsome daughters.

43 Jean Rob, 1643 (c/egd/1291), James Welch, 1662 (c/egd/435), and Anabell Stewart, 1677 (c/egd/1747).

44 For a detailed reconstruction of family relationships and in-law tensions between high status accused witches and their kin accusers, see L. Yeoman, 'Hunting the Rich Witch in Scotland: High-Status Witchcraft Suspects and Their Prosecutors, 1690-1650,' in J. Goodare (ed.), The Scottish Witch-Hunt in Context (Manchester, 2002).

45 Jean Thompsone, 1630 (c/egd/1154) was accused of killing her inlaws with magic.

$46 \quad G S$ v.5 \#370.

47 NAS JC26/9/1.

48 NAS JC26/9/1.

49 SJC, v. I, p.117.

50 See for example, Sarah Cranstoun, 1678 (c/egd/618) and her servant Jennet Burton, 1678 (c/egd/620).

51 Her trial transcripts are printed in $S J C$, vol. I, pp.96-120. See L. Martin, 'The Devil and the Domestic,' PhD thesis (forthcoming) for a full discussion of Isabel Young's case. 